\title{
THE ACCOMPANIMENT NEEDS OF THE FAMILY WITH A LOVED ONE IN THE CRITICAL CARE UNIT
}

\section{Charnell Quinton}

Critical Care Nurse, St George's Hospital, Port Elizabeth

\section{Dalena van Rooyen}

DCur

Senior Lecturer, Nursing Science, University of Port Elizabeth

\author{
Johanita Strümpher \\ DCur \\ Professor of Nursing, University of Port Elizabeth
}

Keywords: accompaniment needs; family; loved one; critical care unit; qualitative research

\begin{abstract}
Nurses have unique opportunities to create environments where patient and family needs can be met. Critical care nurses face the challenge of assisting anxious families to cope with the critical illness of their loved one. There is a great need to humanise the Critical Care Unit and create a warm and caring environment. Caring for a patient's loved ones is challenging, as the family's experience of the patient's admission to the Critical Care Unit is individual and unique. Ensuring the accompaniment of the family with a loved one in the Critical Care Unit provides an excellent standard of professional practice. Concern for the quality of service is a professional responsibility. This research study was divided into three phases. The first phase explores and describes the family experience when a loved one is a patient in the Critical Care Unit. Phase two explores and describes how nurses perceive and interpret the family experience of the Critical Care Unit. These experiences and perspectives were analysed and recurring themes were identified. Finally, in the third phase of the study, guidelines to assist the nurse in the accompaniment of the family in the Critical Care Unit are described.
\end{abstract}

\section{OPSOMMING}

Verpleegkundiges het 'n unieke geleentheid om 'n omgewing te skep waar daar aan die behoeftes van beide die pasiënte en hul gesinslede voldoen word. Verpleegkundiges wat in intensiewe sorgeenhede werk, het die uitdaging om angstige gesinslede te help om die ernstige siekte van 'n geliefde te verwerk en te aanvaar. Daar is ' $n$ groot behoefte by die publiek om die omgewing in ' $n$ intensiewe eenheid te vermenslik sodat hulle warmte en aanvaarding kan ervaar wanneer hulle ' $n$ siek geliefde besoek. Elke gesinslid ervaar 'n geliefde se ernstige siekte en opname in ' $n$ intensiewe eenheid op ' $n$ unieke en individuele wyse. Dit is die verpleegkundige se professionele taak om te verseker dat hierdie ervaring positief is en dat daar in gesinslede se emosionele behoeftes voorsien word. Die studie was in drie fases verdeel. In fase een is die ervarings van gesinslede van 'n geliefde wat in ' $n$ intensiewe eenheid opgeneem is, bepaal. In fase twee is die perspektiewe van verpleegkundiges wat in intensiewe eenhede werk en wat kontak met gesinslede het, bepaal. Hierdie ervarings en perspektiewe is geanaliseer en herhalende temas is geïdentifiseer. In fase drie van die studie word riglyne gegee van hoe verpleegkundiges te werk kan gaan om gesinslede te ondersteun. 


\section{INTRODUCTION STATEMENT}

Critical care nursing has evolved into a prominent speciality requiring highly sophisticated levels of skilled nursing care (Flynn \& Bruce, 1993:1). Critical care nurses thus provide highly technological care to patients with complex multi-system problems. Critical care nurses are frequently under intense pressure for long periods of time and the psychological and social aspects of critical illness may be inadvertently overlooked. The challenge of successfully communicating with anxious relatives may be overwhelming at times, but families need emotional support and should be treated as an extension of the patient (Flynn \& Bruce, 1993:1). A holistic approach to critical care nursing must include the patient's loved ones.

It is the researcher's perception that, although nurses attempt to ease family anxiety, provide information and emotional support, nurses are not meeting the needs of the family. Information given is not always the information the family wants. It would appear that what the family requires from the nurse and that which the nurse perceives the family requires, is not the same. In this study the researcher hoped to explore these differences to improve communication between nurses and families to ensure that the nurses are able to accompany the family in the Critical Care Unit.

\section{AIMS OF THE STUDY}

The aims of this study were:

- To explore and describe the family's experience of the Critical Care Unit when a loved one is a patient in the Critical Care Unit.

- To explore and describe how nurses perceive and interpret the family experience of the Critical Care Unit.

- To develop guidelines that will assist the critical care nurse in the accompaniment of the family in the Critical Care Unit.

\section{DEFINITION OF TERMS}

Loved one refers to a spouse, sibling, child or significant other of the patient and should be at least 18 years of age.
Critical Care Unit also referred to as an Intensive Care Unit, which comprises a medical and surgical Critical Care Unit (Foss \& Tenholder, 1993:381). This particular Critical Care Unit admits a wide variety of patients including:

- the cardiac, respiratory and renal impaired

- those admitted post-operatively following medium to high-risk surgery such as aortic aneurysm repairs, radical prostatectomies, neurosurgery, large orthopaedic operations and those who pose an anaesthetic risk

- those admitted following serious traumarelated injuries such as motor vehicle accidents, near-drowning and snakebites.

Nurse refers to an educated person who is legally authorised to practice nursing within the relevant ethical and legal framework as set out by the Nursing Act, no. 50 of 1978 (Kotze, 1998:8). In the context of this study, a nurse is further defined as registered with the South African Nursing Council as a general nurse, with at least one year experience in the Critical Care Unit.

Experience is the act of living through an event. It also refers to anything and everything observed and lived through (Collins, 1981:300).

Accompaniment is to be or go with as a companion. It is the act of adding completeness or symmetry (American Heritage Dictionary, 2000:24).

\section{RESEARCH DESIGN}

A qualitative design was used to gain insight and understanding of the family's experience of the Critical Care Unit, and how the nurse perceives this experience of the family related to the needs of the family. An explorative and descriptive approach was also used to gain insight into the phenomena of the family experience and the nurses' perception of this experience in a Critical Care Unit (Wilson, 1985:566) and to obtain uninterpreted descriptions (Kvale, 1996:32) to be used to develop specific guidelines that will assist the critical care nurse in the accompaniment of the family of critically ill patients. As no prior assumptions of the accompaniment of the family in the Critical Care Unit were made, a phenomenological approach was used so that an accurate description of the family's lived experience of the Critical Care Unit 
and the nurses' perception of this experience could be obtained (Kvale, 1996:38). Finally, a contextual approach was used as the setting for this research study was a Critical Care Unit in a private hospital in Port Elizabeth (Burns \& Grove, 1993:38).

\section{DATA COLLECTION}

\section{Sampling Method}

A non-probability, purposive sampling strategy was used. Purposive sampling is a method of nonrandomised sampling based on the researcher's judgement to ensure that the sampled population is composed of elements, with specific attributes, necessary for this study (De Vos, 1998:198). Purposive sampling was used to achieve saturation of data by repeating themes and involved the conscious selection of certain members who met the sampling criteria (Mouton, 1996:134). Sampling criteria can be defined as the characteristics that are essential for membership of the target population (Burns \& Grove, 1993:236).

\section{Sample Population and Selection Crite- ria}

There were two research population groups in this particular study:

Group A consisted of immediate family members of patients admitted to the Critical Care Unit. A total of three interviews were conducted, one of which was involved in the pilot study. The participants displayed the following characteristics:

- $\quad$ All the participants were immediate family members:

- The first family interview was conducted with the wife and three daughters of a patient in the Critical Care Unit.

- The next two interviews were conducted with just the wives of patients admitted to the Critical Care Unit.

- $\quad$ The participants were family members of patients who stayed in the Critical Care Unit for a minimum of two weeks.

- The participants were family members of patients who were ventilated in the Critical Care Unit. Two of these patients were ad- mitted under emergency situations, while the third patient was an elective admission for post-operative observation:

- Two of the patients developed respiratory failure in the ward and were then admitted to the Critical Care Unit for ventilation.

- $\quad$ The third patient went to theatre for a partial gastrectomy and was booked for post-operative observation in the Critical Care Unit. This patient then developed respiratory complications and was also ventilated.

- $\quad$ Socio-economically, the participants could be defined as middle class to affluent.

- The interviews were all conducted in English.

- All the participants were Caucasian.

- The participants were 30-60 years old.

A pilot study was conducted with the wife and three daughters of a patient in the Critical Care Unit to identify any problems that may be encountered during the actual study. The family met the sampling criteria as described above. As no problems were encountered, the pilot study was included in the description of the sample.

Group B consisted of interviews with registered nurses in the Critical Care Unit. In total, four interviews were conducted - one of which was also involved in the pilot study. The participants displayed the following characteristics:

- $\quad$ All were registered nurses with at least one year experience in the Critical Care Unit

- Two participants had four years experience in the Critical Care Unit.

- One participant had seven years experience.

- $\quad$ One participant had twelve years experience as well as a post-graduate qualification in Critical Care Nursing Science.

- Three of the participants were female, the other male.

- Participants represented different culture groups.

- The participants were $28-40$ years of age. 
A pilot study was conducted with one registered nurse who met the sampling criteria to identify any problems that may be encountered in the actual study. No problems were identified and the pilot study was included in the description of the sample.

Participants were informed that only the researcher would be aware of their identity. All findings and documents had pseudonyms or code numbers to ensure participator privacy and confidentiality. Participants were also informed that they could withdraw from the interview process at any time. A consent form was signed by all participants agreeing to take part in the study.

\section{Methods of Data Collection}

Unstructured, in-depth interviews were the method of data collection as the researcher sought to understand ideas and attitudes experienced by the participants (Burns \& Grove, 1993:365). This type of interviewing allowed flexibility and made it possible to follow the intents and thoughts of the family and nurses.

The following questions were asked of both research groups:

- Group A: How did you experience the Critical Care Unit during your (loved one's) stay? and

How did you wish to be supported by the registered nurse during this period?

- Group B: How do you perceive the family experience of the Critical Care Unit?

Interviews were tape-recorded and continued until data saturation occurred. The following guidelines, as suggested by Lincoln and Guba, 1985 (in Tutty, Rothery \& Grinnell, 1996:82) were used to determine when data saturation occurred:

- All resources were exhausted, for example, time, budget and limitations on access.

- Data had been collected in categories hoped to be covered.

- Emergence of regularities, overlaps, possible patterns and data duplication occurred more frequently.

- Information was collected that was divergent from the study's central focus.

\section{Methods of Data Analysis}

All interviews were transcribed verbatim. The following eight steps were used to analyse the data according to the descriptive analysis method of Tesch (in Creswell, 1994:155):

(i) Transcriptions were read through carefully and any ideas that came to mind were written down.

(ii) Taking one document at a time, careful analysis to determine underlying information was attempted.

(iii) A list was made of topics that occurred. Similar topics were clustered together and then arranged into major, unique and leftover topics.

(iv) Taking the list back to the data, topics were abbreviated as codes. These codes were written next to the appropriate segments of the text. This preliminary organising scheme was used to determine whether new categories or codes emerged.

(v) The most descriptive wording for the topics was used as categories. Grouping related and interrelated topics together reduced the total list of categories.

(vi) A final decision on the abbreviation for each category was made and these codes were alphabetised.

(vii) A preliminary analysis on assembled data in each category was then performed.

(viii) If necessary, existing data was re-coded (Creswell, 1994:155).

Use of an independent coder ensured triangulation of data. Triangulation refers to the use of multiple methods to collect and interpret data to converge on an accurate representation of reality (Brink, 1996:215). The independent coder was a nurse researcher familiar with qualitative data analysis, who analysed the interviews independently of the researcher according to the protocol used by the researcher regarding the method used for analysis. After this separate interview analysis, both met for a consensus discussion to ensure that the data reflected was accurate.

\section{DESCRIPTION OF RESULTS}

The results of this two-fold research study can be sum 
marised in the following two tables:

Table 1 illustrates the major themes and sub-themes of the family experience of the Critical Care Unit when a loved one is a patient in the Critical Care Unit.

Table 2 illustrates the major themes and sub-themes of how nurses perceive and interpret the family experience of the Critical Care Unit.
Both groups were included in the study as it was the researcher's objective to explore any similarities and differences between the actual family experience of the Critical Care Unit and how nurses perceive the family would experience the admission and stay of a loved one in the Critical Care Unit.

Table 1: Major themes and sub-themes of the family experience when a loved one is a patient in the critical care unit

\begin{tabular}{|c|c|}
\hline MAJOR THEMES & SUB-THEMES \\
\hline \multirow[t]{5}{*}{$\begin{array}{l}\text { 1. The family experience emotional } \\
\text { turmoil related to the admission and } \\
\text { stay of a loved one in the Critical Care } \\
\text { Unit. }\end{array}$} & $\begin{array}{l}\text { The family experienced the following emotions: } \\
\text { 1.1 Shock related to admission to the } \\
\text { Critical Care Unit and the } \\
\text { diagnosis of the loved one }\end{array}$ \\
\hline & $\begin{array}{l}\text { 1.2 Fear of death of a loved one and } \\
\text { fear of the technological } \\
\text { environment }\end{array}$ \\
\hline & $\begin{array}{l}\text { 1.3 Anxiety related to not being able } \\
\text { to spend more time with the } \\
\text { loved one }\end{array}$ \\
\hline & $\begin{array}{l}\text { 1.4 Disappointment if the loved one } \\
\text { does not progress as well as } \\
\text { expected }\end{array}$ \\
\hline & $\begin{array}{l}1.5 \text { All family members experienced } \\
\text { emotional turmoil }\end{array}$ \\
\hline \multirow[t]{5}{*}{$\begin{array}{l}\text { 2. The family experience certain needs } \\
\text { when a loved one is a patient in the } \\
\text { Critical Care Unit. }\end{array}$} & $\begin{array}{l}\text { The family experienced the following needs: } \\
\text { 2.1 The need to maintain hope with regard to the loved } \\
\text { one's condition and prognosis }\end{array}$ \\
\hline & $\begin{array}{l}\text { 2.2 The need to be involved with regard to decision- } \\
\text { making for the loved one }\end{array}$ \\
\hline & $\begin{array}{l}\text { 2.3 The need for information with } \\
\text { regard to the loved one's } \\
\text { condition and prognosis }\end{array}$ \\
\hline & $\begin{array}{l}\text { 2.4 The need for truth and honesty } \\
\text { in explanations }\end{array}$ \\
\hline & $\begin{array}{l}\text { 2.5 The need for orientation in the } \\
\text { Critical Care Unit. }\end{array}$ \\
\hline
\end{tabular}


Table 2: Major themes and sub-themes of how nurses perceive and interpret the family experience of the critical care unit

\begin{tabular}{|c|c|}
\hline MAJOR THEMES & SUB-THEMES \\
\hline \multirow[t]{2}{*}{$\begin{array}{l}\text { 1. Nurses are aware of the } \\
\text { emotional turmoil that the family } \\
\text { experience related to the } \\
\text { admission and stay of their } \\
\text { loved one in the Critical Care } \\
\text { Unit. }\end{array}$} & $\begin{array}{l}\text { The family's experience of emotions was described as } \\
\text { follows by the nurses: } \\
1.1 \text { Nurses perceive that the family experience fear } \\
\text { related to the possible death of their loved one, } \\
\text { related to the unfamiliar milieu and related to the } \\
\text { financial implications of a loved one's stay in the } \\
\text { Critical Care Unit }\end{array}$ \\
\hline & $\begin{array}{l}\text { 1.2 Nurses perceive that the family experience frustration } \\
\text { related to not knowing what to expect in the Critical } \\
\text { Care Unit, related to neglect and lack of comfort from } \\
\text { the nursing staff and related to exclusion in decision- } \\
\text { making on behalf of their loved one }\end{array}$ \\
\hline \multirow[t]{2}{*}{$\begin{array}{l}\text { 2. Registered nurses are aware of } \\
\text { the needs and problems that } \\
\text { families experience in the } \\
\text { Critical Care Unit. }\end{array}$} & $\begin{array}{l}\text { Nurses perceive that the family experience the following } \\
\text { needs and problems: } \\
\text { 2.1 Nurses perceive that the family } \\
\text { experience certain needs with regard to } \\
\text { information of their loved one's condition } \\
\text { and prognosis, with regard to truth and } \\
\text { honesty in explanations and with regard to } \\
\text { orientation in the Critical Care Unit to } \\
\text { routine, equipment and procedures }\end{array}$ \\
\hline & $\begin{array}{l}\text { 2.2 Nurses perceive that the family experience } \\
\text { problems associated with hesitancy in } \\
\text { pproaching doctors with their enquiries } \\
\text { and associated with not trusting nursing } \\
\text { staff related to the lack of time that nurses } \\
\text { are able to spend with the family. }\end{array}$ \\
\hline
\end{tabular}

\section{SIMILARITIES IN FINDINGS BETWEEN THE TWO RESEARCH GROUPS}

Both research populations have identified the emotional turmoil suffered by the family when a loved one is critically ill. In a study by Forrester, Murphy, Price and Monaghan (1990:655) it was found that family members of Critical Care patients experienced severe stress and anxiety during the critical illness and subsequent hospitalisation of a loved one.
Both sample populations identified fear of death of a loved one and fear of the unfamiliar milieu in the Critical Care Unit. Support for these observations can be found in the following literature resources: Wallace-Barnhill (in Civetta, Taylor \& Kirby, 1992:77) states that regardless of how family members present themselves, whether stoic, seemingly unemotional and in control, or out of control and behaving hysterically, the most overriding concern is fear of death for their loved one. Families of critically ill patients may feel generally lost 
in the complex atmosphere of machines, dials and tubes (Jacono, Hicks, Antonioni, O’Brien \& Rasi, 1990:74). Long and Greeneich (1994:108) state that the hi-tech environment of the Critical Care Unit makes it imperative that nurses are able to use the equipment properly, interpret data accurately and trouble-shoot malfunctioning equipment. Any sign of incompetence in these areas may lead to family dissatisfaction and fear for the loved one.

The research groups also both identified the family experience of being excluded from decision-making on behalf of their loved one. Wallace-Barnhill (in Civetta et al. 1992:78) states that families feel immobilised by their inability to control the outcome of the patient's life and this results in feelings of helplessness. In a study by Carr (1997:85) it is suggested that nurses can create a climate where families believe that their role as nurturers cannot be replaced, where support provided by the patient's and family's network is facilitated. It is also suggested that family-professional collaboration should be promoted at all levels of health care. Benefits of involvement for the family members include satisfying their need to be with the patient, preserving the family unit and easing the transition from institution to home.

Nurses and families identified the need for more information related to the condition and prognosis of the loved one. Davis-Martin (1994:515) concluded that over the past 13 years research on the needs of families of patients in the Critical Care Unit has consistently identified information as one of the ten most important needs. Families reported needing to receive information on a regular basis. Eighty-eight percent of the respondents in Davis-Martin's study wanted to know the prognosis of their loved one and $80.8 \%$ wanted to know specific facts concerning the patient's progress.

The need for truthful and honest information with regards to the loved one's condition and prognosis was identified by both research populations. Price, Forrester, Murphy and Monaghan (1991:184) confirm the need for honesty in their research study of 213 family members. They report that the highest priority of relatives during the hospitalisation of a loved one in a Critical Care Unit is the relief from anxiety and the need for honest information.

The need for orientation related to routine, equipment and procedures in the Critical Care Unit was also identified by both research populations. In a study by Halm and Titler (1993:415) it was found that difficulties that nurses have in providing care to families of critically ill patients have been attributed to limitations in time and skill of nurses and availability of research-based knowledge. It was noted that critical care nurses must integrate family members as recipients of care, not just the ill patient. Krozek (1991:53) suggests that hospitals develop a brochure that informs families of the Critical Care Unit's rules and regulations, including the policy and visiting hours as well as where to find the cafeteria, rest rooms and telephones. He also states that written information is no substitute for talking with the family. The family should be given a quick tour of the unit to orientate them to the unfamiliar environment.

\section{DIFFERENCES IN FINDINGS BETWEEN THE TWO RESEARCH GROUPS}

Although both research populations described the experience of emotional turmoil, the family further described how this emotional turmoil had a resulting negative effect on the rest of their family life. All aspects of their family life were affected and the emotional turmoil did not occur in isolation. Doherty, Plowfield, Ware and West (in Bucher \& Melander, 1999:55) state that patients live within the context of a family and because it is within this context that they will return, critical care nursing requires that nurses look beyond the patient to the family members. As a family is a system, each person's actions within the family can affect every other member.

Registered nurses perceived that family members might fear the financial implications of a loved one in a Critical Care Unit, yet the family members interviewed did not verbalise this concern. Fear of financial implications is highlighted in Doherty et al. (in Bucher \& Melander, 1999:61). They state that critical illness frequently has many financial consequences for the family.

Registered nurses identified problems, such as family members perceived as hesitant of approaching doctors with their enquiries and family members not trusting the nurses, that hinder the development of a trusting relationship between medical staff and the family. In the interviews with the family, no mention of reluctance 
with regard to approaching the doctors or any feelings of mistrust of the nursing staff were mentioned. This finding is in contrast to the results of a study by Price et al. (1991:186) that found that family members of a critically ill patient listed speaking to the doctor everyday as more important than speaking to the registered nurse everyday. It was found that the doctor's opinion of the critically ill patient was more valued than the opinion of the nurse. In a study by Jamerson, Scheibmeir, Bott, Crighton, Hinton and Cobb (1996:471), it was found that families wanted information from the physicians regarding the patient's status. No literature was found that supported the perception that family members were hesitant of approaching doctors with their enquiries.

\section{RESEARCHER'S EXPERIENCE}

This description of the researcher's experience is derived from field notes that were compiled directly after each interview with the family and the nurse.

From the interviews conducted with the family members of loved ones in the Critical Care Unit, it is the researcher's belief that, although the family were very grateful to the nurses for the care rendered to their loved one, family members of critically ill patients felt that more time should be spent explaining the disease process and environment of the Critical Care Unit.

It is the researcher's belief that nurses felt it was the doctors' responsibility to explain the disease process and possible prognosis to the family. Nurses appeared to experience a sense of guilt related to not spending enough quality time with family members of critically ill patients. Time constraints were blamed for this.

In general, the researcher believes that nurses have a good understanding of the family experience of the Critical Care Unit. However, it appears that nurses are not always meeting the needs of the family. Nurses are aware of not meeting this need and this results in feelings of dissatisfaction and inadequacy.

GUIDELINES TO OPTIMISE THE ACCOMPANIMENT OF FAMILIES WITH A LOVED ONE IN THE CRITICAL CARE UNIT
Based on the findings of this study, the researcher developed guidelines for registered nurses working in the Critical Care Unit. These guidelines were formulated to address the needs as identified by the families involved in this research study. It is the researcher's intention that these recommendations be used to assist the registered nurse in the accompaniment of the family when their loved one is a patient in the Critical Care Unit.

\section{Establishing and maintaining a therapeutic relationship}

A therapeutic relationship can be described as a relationship where one member deliberately uses interactive skills to encourage and support the other (Abraham \& Shanley, 1992:153). Nurses need to acquire, develop and utilise interactive skills to accompany the family when a loved one is critically ill. The foundation of a therapeutic relationship is the capacity of the nurse to show respect for the autonomy, dignity and healing potential that exists within the family (Barry, 1996:56). In order for a therapeutic relationship to develop it is imperative for open communication between the family members of a critically ill patient and the registered nurse.

\section{Techniques for therapeutic communica- tion}

Therapeutic communication in the Critical Care Unit refers to open communication that facilitates sharing of fears, concerns and wishes between the family and the nurse. Critical care nurses face the challenge of giving hope within the context of the reality of the illness and the limitations of the treatment (Barry, 1996:427). The communication techniques found in Kozier, Erb and Oliviera (1991:258) suggested by the researcher include:

- Attentive listening

- Paraphrasing

- Clarifying

- Use of open-ended questions and statements

- Focusing

- Specific, tentative and informative responses

- The use of touch

- Using silence

- Providing general leads

- Summarising. 


\section{Creating a therapeutic milieu}

A therapeutic milieu in the Critical Care Unit can be explained as an environment where the nurse assists the patient and family to find security and balance in the situation (Mellish \& Paton, 2000:14). The researcher believes that emotional security and physical safety are characteristic of a therapeutic milieu. A therapeutic milieu also refers to a physically safe and comfortable environment. People usually communicate at ease in a comfortable environment. Temperature extremes, excessive noise and a lack of privacy can all interfere with communication (Kozier et al. 1991:253). The researcher recommends the use of a private, close proximity room where the nurse can communicate with the family away from the interruptions and distractions of the Critical Care Unit. A private room will also provide an opportunity for the family to be alone if they so desire.

\section{Developing an orientation programme for patients and their family in the Critical Care Unit}

Wherever possible, the researcher suggests that a preadmission orientation programme should be implemented not only for the patient, but for the patient's immediate family as well. Patients and family should be brought to the Critical Care Unit before theatre, where possible. Obviously this is not always possible as a large percentage of admissions to the Critical Care Unit are emergency admissions. Although the situation is not ideal the patient, if conscious, and the family should be orientated to the Critical Care Unit as soon as possible. The following should be included in the orientation programme:

\section{Orientation to the immediate environment}

- Introducing staff to the family

- Information pamphlet

- Contact telephone numbers

- Orientation to surroundings with regard to monitors and equipment

- Orientation to the Critical Care Unit routine with regard to doctor's rounds, washing of patients and meal times

- Visitation policy

- Assisting the family at the bedside. For example: families are often intimidated by the monitors and equipment surrounding their loved one and may need direction from the nurses to touch their loved one.

\section{Provision of support structures to facili- tate effective family coping}

Nurses are part of a multidisciplinary team and should be encouraged to refer families to the necessary experts available. The researcher suggests that counselling professionals be available for families who appear to be unable to cope with the illness of their loved one. The names and telephone numbers of available counselling services could be included in the information pamphlet.

\section{Preparation of staff in the Critical Care Unit}

Competence in care within a technological environment is vitally important to both patients and their significant others. The registered nurse in the Critical Care Unit must have the necessary knowledge and skill to work in a high stress environment with critically ill patients. However, the registered nurse must also be able to provide emotional support to meet the needs of families of loved ones admitted to the Critical Care Unit. The researcher believes that qualities such as empathy and emotional maturity are of vital importance.

\section{Personnel Support}

It is the researcher's belief that if the registered nurse is to provide support to the family of a loved one in the Critical Care Unit, then the needs of the registered nurse must also be taken into consideration. Health institutions need to be sensitive to the needs of their staff and provide adequate personnel support. High levels of stress can be expected in the Critical Care Unit. Interpersonal relationships can be a source of stress for nurses working in the Critical Care Unit. Dealing with difficult patients, families and other health team members can result in stress for the nurse. Conflict with administration and management can be another area of interpersonal stress for the nurse.

\section{Implementing stress management programmes}

Management can implement education programmes that can assist nurses in dealing with the stress of working in the Critical Care Unit in many positive ways. Registered nurses need to be aware of the techniques 
of stress management in order to accompany the family who experiences stress when their loved one is a patient in the Critical Care Unit.

\section{Crisis intervention in the Critical Care Unit}

The researcher believes that crisis intervention plays an important role in the accompaniment of families in the Critical Care Unit. Due to the severity of illness of the family's loved one, the family may experience a state of crisis. Nurses need to identify potential crisis situations in order to assist and promote family coping. Open and honest communication is necessary to accompany the family, but nurses often find it difficult to communicate with the family.

\section{Implementing comprehensive policies and standards for the accompaniment of the family in the Critical Care Unit}

Standards serve as guides for the provision of care and serve as criteria for evaluating care (Bucher \& Melander, 1999:40). Standards must be clearly defined and validated by somebody of authority. The researcher suggests that the patient's family be included in evaluating the quality of care rendered. This can be done through questionnaires or interviews with the family to determine if the patient needs as well as the family needs were adequately met. The information from the questionnaires and interviews should be carefully studied to identify areas where families feel that their needs are not adequately met. This process then serves as a standard to improve the quality of care delivered to the family of a loved one in the Critical Care Unit.

\section{Research and research utilisation in the Critical Care Unit}

Research is a critical component of nursing practice. Critical care nurses must be committed to participation in research studies to improve the quality of care delivered to the critically ill patients and their families. However, new data is useless if it is not applied and used in the clinical setting. Improving nursing care requires a commitment from nurses to read and use research findings.

\section{LIMITATIONS}

The following limitations were identified in this study by the researcher:

- The scope of this study was limited to a Critical
Care Unit in a private institution where the researcher is currently employed.

- This study was limited to the family experience of the Critical Care Unit when a loved one is critically ill. In the interviews conducted with registered nurses only their perception of the family experience was explored. The nurses' own experience of emotional turmoil in the Critical Care Unit was not explored.

\section{CONCLUSION}

From this study the researcher has realised that the admission and stay of a loved one in the Critical Care Unit is very traumatic for the family. Nurses appear to have insight into the family experience, but more education and training is needed to assist nurses in dealing more effectively with the needs of the family.

The aim of this study was to publicise the needs of the family during the admission and stay of a loved one in the Critical Care Unit. The researcher hopes that by promoting awareness on the topic, nurses will be more sensitive to the needs of the family and better equipped to provide effective support to meet the family needs.

\section{BIBLIOGRAPHY}

American Heritage Dictionary of the English Language; $4^{\text {th }}$ edition 2000. Houghton: Miffon.

ABRAHAM, C \& SHANLEY, E 1992: Social Psychology for Nurses: Understanding Interaction in Health Care. London: Edward Arnold. BARRY, PD 1996: Psychosocial Nursing: Care of the Physically III Patients and their Families; $3^{\text {rd }}$ edition. Philadelphia: Lippincott. BRINK, HI 1996: Fundamentals of Research Methodology for Health Care Professionals. Cape Town: Juta.

BUCHER, L \& MELANDER, S 1999: Critical Care Nursing. Philadelphia: WB Saunders.

BURNS, N \& GROVE, SK 1993: The Practice of Nursing Research: Conduct, Critique and Utilization; $2^{\text {nd }}$ edition. Philadelphia: WB Saunders.

CARR, JM 1997: The Family's Experience of Vigilance: Challenges for Nursing. Holistic Nursing Practice, 11(4):82-88.

CIVETTA, JM; TAYLOR, RW \& KIRBY, RR 1992: Critical Care; $2^{\text {nd }}$ edition. Philadelphia: JB Lippincott.

COLLINS POCKET ENGLISH DICTIONARY 1981. London: HarperCollins.

CRESWELL, JW 1994: Research Design: Qualitative and 
DAVIS-MARTIN, S 1994: Perceived Needs of Families of LongTerm Critical Care Patients: A Brief Report. Heart and Lung, 23(6):515-518.

DE VOS, AS 1998: Research at Grassroots. A Primer for the Caring Professions. Pretoria: JL van Schaik.

FLYNN, J-BM \& BRUCE, NP 1993: Introduction to Critical Care Skills. St. Louis: Mosby.

FORRESTER, DA; MURPHY, PA; PRICE, DM \& MONAGHAN, JF 1990: Critical Care Family Needs: Nurse-Family Member Confederate Pairs. Heart and Lung, 19(6):655-661.

FOSS, KR \& TENHOLDER, MF 1993: Expectations and Needs of Persons with Family Members in an Intensive Care Unit as opposed to a General Ward. Southern Medical Journal, 86(4):380-384. HALM, MA \& TITLER, MG 1993: Behavioral Responses of Family Members during Critical Illness. Clinical Nursing Research, 2(1):414-438.

JACONA, J; HICKS, G; ANTONIONI, C; O'BRIEN, K \& RASI, M 1990: Comparison of Perceived Needs of Family Members between Registered Nurses and Family Members of Critically III Patients in Intensive Care and Neonatal Intensive Care Units. Heart and Lung, 19(1):73-78.

JAMERSON, PA; SCHEIBMEIR, M; BOTT, MJ; CRIGHTON, F; HINTON, RH \& COBB, AK 1996: The Experiences of Families with a Relative in the Intensive Care Unit. Heart and Lung, 25(6):467474.

KOTZE, WJ 1998: An Anthropological Nursing Science: Nursing Accompaniment Theory. Health SA Gesondheid, 3(3):3-14.

KOZIER, B; ERB, G \& OLIVIER, R 1991: Fundamentals of Nursing. Concepts, Process and Practice; $4^{\text {th }}$ edition. Redwood City: Addison-Wesley.

KROZEK, CF 1991: Helping Stressed Families in an ICU. Nursing, January 1991:52-55.

KVALE, S 1996: An Introduction to Qualitative Research Interviewing. Thousand Oaks: Sage.

LONG, CO \& GREENEICH, DS 1994: Family Satisfaction Techniques: Meeting Family Expectations. Dimensions of Critical Care Nursing, 13(2):104-111.

MELLISH, JM \& PATON, F 2000: An Introduction to the Ethos of Nursing; $2^{\text {nd }}$ edition. Johannesburg: Heinemann.

MOUTON, J 1996: Understanding Social Research. Pretoria: Van Schaik.

PRICE, DM; FORRESTER, A; MURPHY, PA \& MONAGHAN, JF 1991: Critical Care Family Needs in an Urban Teaching Medical Center. Heart and Lung, 20(2):183-188.

TUTTY, LM; ROTHERY, MA \& GRINNELL, RM (Jr.) 1996: Qualitative Research for Social Workers: Phases, Steps and Tasks. London: Allyn and Bacon.

WILSON, HS 1985: Research in Nursing. California: Addison- 